NATIONAL LABORATORY

\title{
DEVELOPMENT OF A LOW-COST HEAT PUMP WATER HEATER - FIRST PROTOTYPE
}

September 2005

Prepared by

V. C. Mei and J. J. Tomlinson

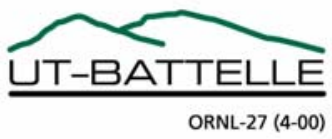




\title{
DOCUMENT AVAILABILITY
}

Reports produced after January 1, 1996, are generally available free via the U.S. Department of Energy (DOE) Information Bridge.

\section{Web site http://www.osti.gov/bridge}

Reports produced before January 1, 1996, may be purchased by members of the public from the following source.

\author{
National Technical Information Service \\ 5285 Port Royal Road \\ Springfield, VA 22161 \\ Telephone 703-605-6000 (1-800-553-6847) \\ TDD 703-487-4639 \\ Fax 703-605-6900 \\ E-mail info@ntis.gov \\ Web site http://www.ntis.gov/support/ordernowabout.htm
}

Reports are available to DOE employees, DOE contractors, Energy Technology Data Exchange (ETDE) representatives, and International Nuclear Information System (INIS) representatives from the following source.

Office of Scientific and Technical Information

P.O. Box 62

Oak Ridge, TN 37831

Telephone 865-576-8401

Fax 865-576-5728

E-mail reports@osti.gov

Web site http://www.osti.gov/contact.html

This report was prepared as an account of work sponsored by an agency of the United States Government. Neither the United States Government nor any agency thereof, nor any of their employees, makes any warranty, express or implied, or assumes any legal liability or responsibility for the accuracy, completeness, or usefulness of any information, apparatus, product, or process disclosed, or represents that its use would not infringe privately owned rights. Reference herein to any specific commercial product, process, or service by trade name, trademark, manufacturer, or otherwise, does not necessarily constitute or imply its endorsement, recommendation, or favoring by the United States Government or any agency thereof. The views and opinions of authors expressed herein do not necessarily state or reflect those of the United States Government or any agency thereof. 
ORNL/TM-2007/154

Engineering Science and Technology Division

DEVELOPMENT OF A LOW-COST HEAT PUMP WATER HEATER FIRST PROTOTYPE

\author{
V. C. Mei \\ J. J. Tomlinson
}

September 2005

\author{
Prepared by \\ OAK RIDGE NATIONAL LABORATORY \\ Oak Ridge, Tennessee 37831-6283 \\ managed by \\ UT-BATTELLE, LLC \\ for the \\ U.S. DEPARTMENT OF ENERGY \\ under contract DE-AC05-00OR22725
}




\title{
DEVELOPMENT OF A LOW-COST HEAT PUMP WATER HEATER
}

\begin{abstract}
Until now the heat pump water heater (HPWH) has been a technical success but a market failure because of its high initial cost. Oak Ridge National Laboratory (ORNL) was tasked to examine commercially available HPWH product technology and manufacturing processes for cost saving opportunities. ORNL was also tasked to verify the technical feasibility of the cost saving opportunities where necessary and appropriate. The objective was to retain most of the HPWH's energy saving performance while reducing cost and simple payback period to approximately three years in a residential application.
\end{abstract}

Several cost saving opportunities were found. Immersing the HPWH condenser directly into the tank allowed the water-circulating pump to be eliminated and a standard electric resistance storage water heater to be used. In addition, designs could be based on refrigerator compressors. Standard water heaters and refrigerator compressors are both reliable, mass produced, and low cost.

To verify the feasibility of these cost saving measures, ORNL completed a conceptual design for an HPWH based on an immersed condenser coil that could be directly inserted into a standard water heater tank through a sleeve affixed to one of the standard penetrations at the top of the tank. The sleeve contour causes the bayonet-style condenser to helix while being pushed into the tank, enabling a condenser of sufficient heat transfer surface area to be inserted.

Based on this design, ORNL fabricated the first laboratory prototype and completed preliminary laboratory tests in accordance with the DOE Simulated Use Test Procedure. Hardening during double-wall condenser fabrication was not overcome, so the prototype is single-walled with a liner. The prototype unit was found to have an energy factor of 2.02, verifying that the low-cost design retains most of the HPWH's energy saving performance. Industry involvement is being sought to resolve the fabrication issue and quantify progress on reducing cost and simple payback period to approximately three years in a residential application. This report provides information on the design, prototype construction, laboratory test data, and analyses of this HPWH. 


\section{A. Introduction}

In FY03 and 04, with the support of DOE and the Tennessee Valley Authority, ORNL developed and tested an HPWH design based on a linear condenser that was immersed in the water tank. This condenser was comprised of two "U-tube" circuits (four legs), each made from 3/8-in. copper tubing for a total of $4.7 \mathrm{sq} \mathrm{ft}$ of heat transfer area. The condenser design required that a special tank be made with a 2.5-in. threaded hole at the top to allow the condenser assembly to be inserted. Two of these HPWHs (termed immersed direct exchange, or IDX) were constructed, lab tested, and field tested as part of a field demonstration of the immersed condenser design. The compressor used in the IDX work had a relatively large capacity (1-ton nominal) to reduce the need for backup electric resistance heating or eliminate it entirely. This work ended in 2004 with the completion of two field tests, one of which was fully successful and the other partially successful. The best-performing unit showed a lab-measured EF of 1.79. Field test results from this unit are summarized in Figure 1 and documented in a report (Mei and Suhartoyo 2004).

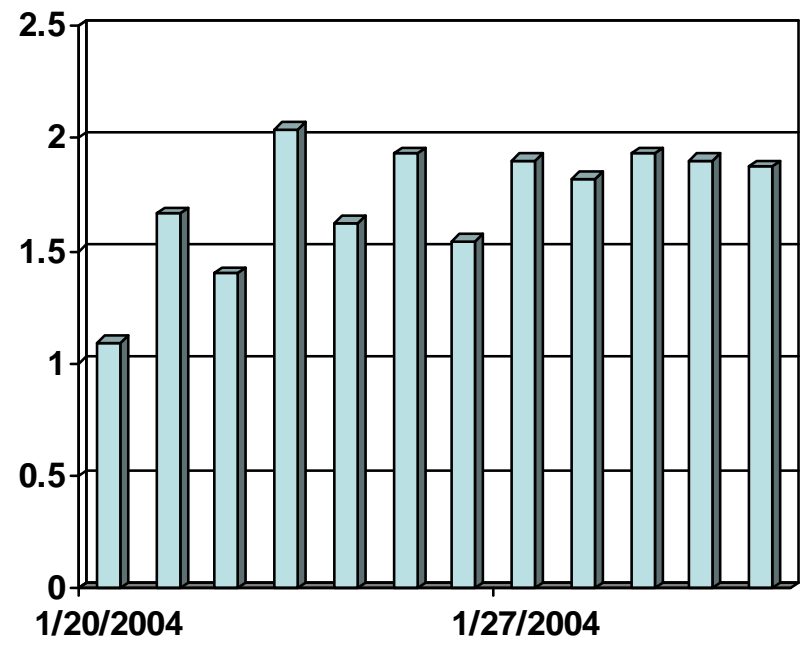

Fig. 1. Field-delivered IDX-HPWH COPs at the demonstration house, January 04.

Although cost estimates exclusive of the tank showed that the assembled IDX HPWH should cost $\$ 150$, the fact that it required a special tank was problematic because of its added cost and lack of interest by water heater tank manufacturers. However, the IDX work did suggest that if there were a simple way to install a large-surface-area, immersed condenser into a conventional insulated electric storage water heater, significant cost reduction could be achieved through use of standard, mass-produced tanks.

Based on a recent idea to address this need, ORNL initiated research on a new condenser design concept. In this new design, shown in Figure 2, a flexible linear condenser rod is inserted through one of the 7/8-in holes on top of the tank using a bent sleeve through which the condenser rod is pushed. As the tube is pushed through the sleeve, it forms a 


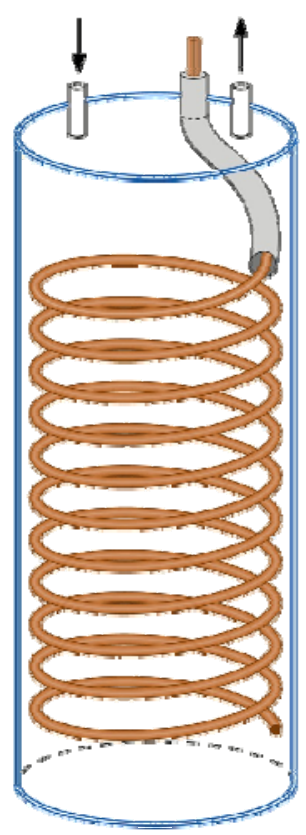

Fig. 2. New IDX HPWH condenser coil design.

coil automatically. This new design allows an ordinary water tank to be used for HPWH applications. This invention eliminates the need for a specialty tank and a water circulating pump.

In FY05, ORNL completed initial laboratory development and testing of the low-cost condenser design. We successfully formed the double-wall tube with $1 / 2$-in and 7/16-in copper tubing provided by Wolverine as shown in Figure 3. However, we found that the coil forming process, including hydraulically expanding the inner tube to form a firm bond with the outer tube, hardened the double-wall tube, making it difficult to insert into the tank without kinking or crushing. Softening (annealing) the hardened double-wall tube solves the problem, but requires heating the tube to $1000^{\circ} \mathrm{F}$ and then allowing it to cool down slowly (Mei 2005). Although equipment such as induction heating systems may be successfully used for this purpose, we continued to pursue lower-cost options such as cold formed tubes that were single-walled but with an inner liner.

From the previous heat transfer tests performed at ORNL, we determined that the total heat transfer for a single tube (inner tube with smaller diameter) and the double-wall tube were almost identical. The single tube has a smaller heat transfer area than the double-wall tube. However, contact resistance between the inner and outer tubes inhibits heat transfer. For laboratory testing, we inserted a single-wall tube into the tank, as shown in Figure 4, to experimentally study the heat transfer characteristics and energy efficiency that can be achieved with this new coil design. A double-walled tube will be inserted into the tank after we test and confirm a way to soften the coil.

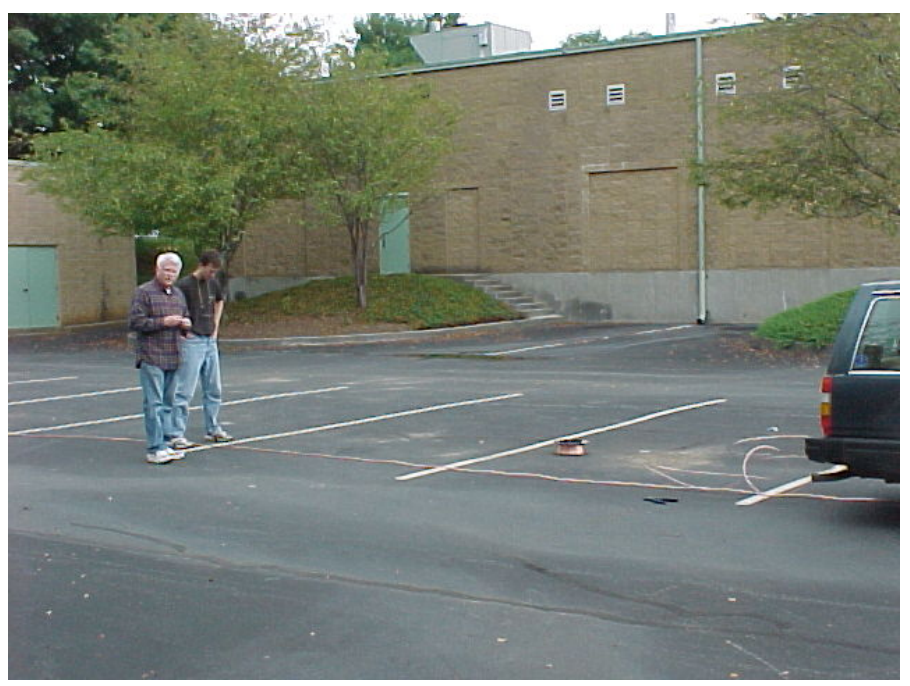

Fig. 3. Inserting 7/16-in. copper tube into $1 / 2-$ in. tube to form a double-wall coil.
For the single-wall condenser coil design, a $1 / 4-$ in. Teflon tube was selected as the inner tube to form a tube-in-tube heat exchanger. Teflon was selected for its flexibility and easy insertion. The Teflon tube is also very tough. It could withstand the pressure for heat pump application, and it can be used at high temperature $\left(500^{\circ} \mathrm{F}\right)$. When we completed the soldering of copper tubes together, with a Teflon tube inside the copper tubing, the Teflon tube was then examined and showed no trace of damage. Teflon is also an 
excellent insulating material, which will reduce the heat exchange between the gas and the liquid refrigerant (inlet and outlet of the condenser coil).

\section{B. Test Setup \\ B.1. Water Tank}

A 66-gal water tank made by the American Water Heating Co. was used for the test. It had 3-in. foam insulation around the tank wall. After $70 \mathrm{ft}$ of 7/16-in. copper tubing was inserted into the tank, it held $492 \mathrm{lb}$ of water, or 58.97 gal.

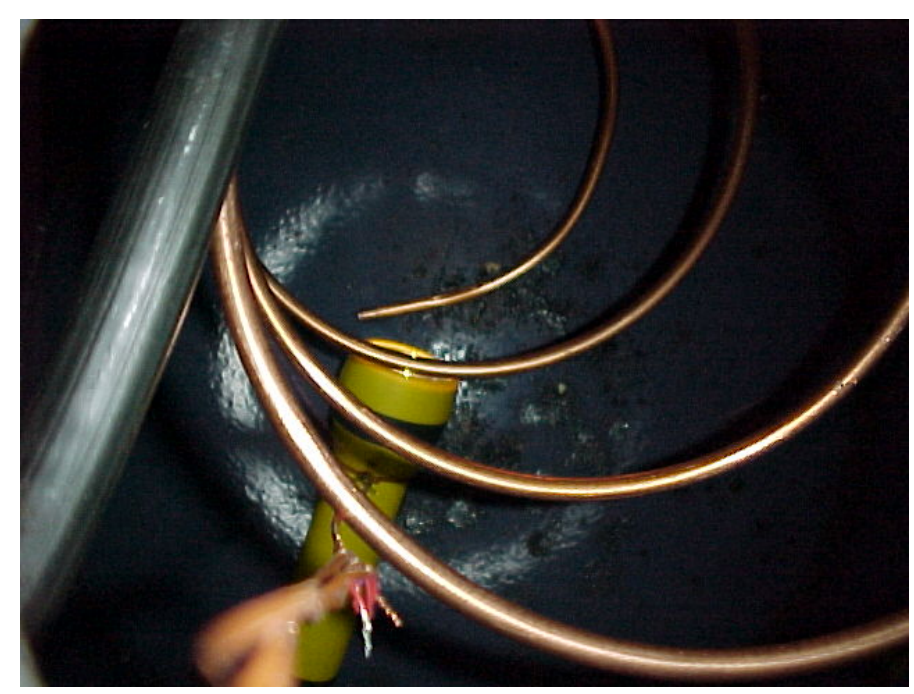

Fig. 4. A single-wall coil inside a water tank.

\section{B.2. Insertion of Condenser Coil}

We planned to insert $70 \mathrm{ft}$ of 7/16-in. tube into the tank. However, after $35 \mathrm{ft}$ was easily inserted, the tip of the tube touched the bottom of the tank and got stuck. (This problem will be avoided in the future design by reducing the pitch of the coil.) We then cut the tube off, and the remaining $35 \mathrm{ft}$ of tubing was inserted into the tank through another 7/8in. hole on the top of the tank. The two condenser coils were connected in parallel, both with $1 / 4$-in. inner Teflon tubes, to form two tube-in-tube heat exchangers.

\section{B.2. Heat Pump}

We used an Embraco HBK10 reciprocating compressor as the engine for the test HPWH. This is the type of compressor used successfully in the EMI WatterSaver HPWH, which uses a wraparound condenser. We used a test HPWH platform with an evaporator, a modified TVX, and refrigeration fittings to fabricate the vapor compression part of the HPWH. The two liquid return lines were combined into a single line before the evaporator. Two shut-off valves were installed on the two liquid lines to allow flow balancing if needed.

\section{Twenty-Four-Hour Laboratory Test of HPWH}

A 24-h test of the HPWH was performed at a singleroom environmental chamber at ORNL (Figure 5). The room temperature was set at $67.5^{\circ} \mathrm{F}$ at $50 \%$ relative humidity. The tank inlet water temperature was set at

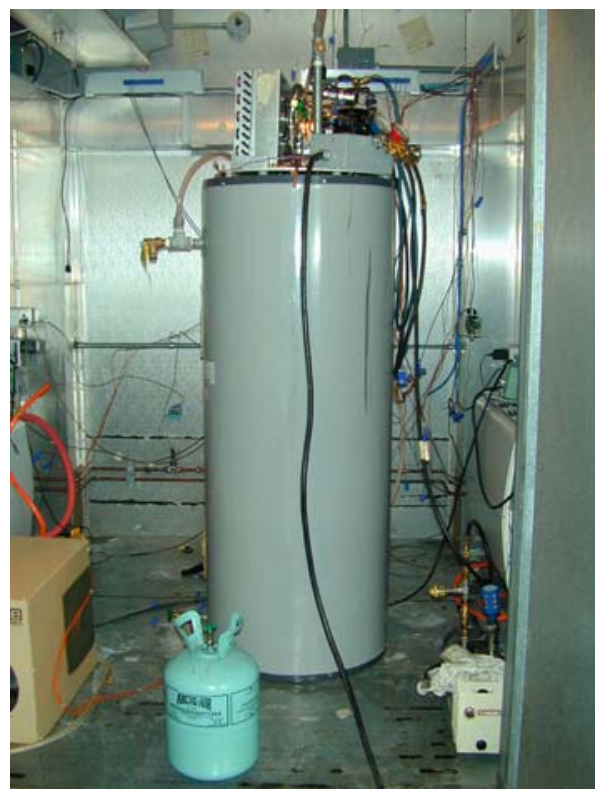

Fig. 5. HPWH test setup. 
$58^{\circ} \mathrm{F}$. These and other test conditions were set according to the 1998 Federal Standard for Water Heater Testing (24-h Simulated Use Test), Part B, Title III, Energy Policy and Conservation Act, 42 U.S.C. 6291-6309, Appendix E to Subpart B of Part 430).

The tank was heated by the heat pump until the average water temperature was at $140^{\circ} \mathrm{F}$. Then six hourly water draws of 10.77 gal were made at a rate of slightly more than $3 \mathrm{gpm}$ (taking 3.2 to 3.4 minutes each). After six draws in six hours, the heat pump ran until the tank water temperature was recovered, or it was shut off by the thermostat on the tank.

The tank water temperatures, total power consumption, compressor suction, and discharge pressures were recorded. Figure 6 shows the power consumption and the average water temperature variation during the 24-hour period. The figure indicates that the water at the top of the tank was never lower than $107^{\circ} \mathrm{F}$, even after six draws. The water tank temperature was completely recovered after less than 8 hours of heat pump operation. The heat pump was off for the remaining portion of the 24-hour test.

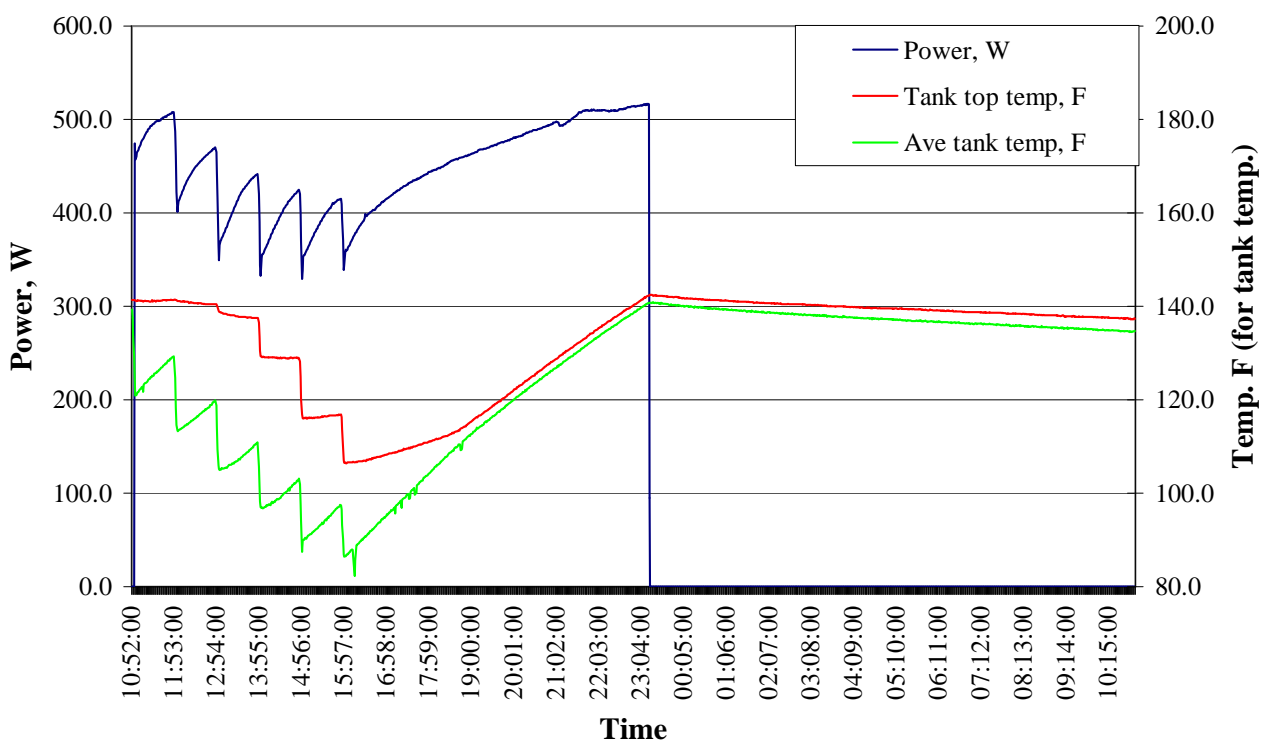

Fig. 6. HPWH power consumption and tank water temperatures

Figure 7 shows the compressor discharge and suction pressure variation during the 24hour test. The compressor discharge pressure was never higher than $260 \mathrm{psi}$, which is well within safe compressor operating range. It also shows that the suction and discharge pressures crossed after the heat pump was off. This could be caused by refrigerant migration from hot to cold spots, which would also dissipate heat from the tank to ambient air. This part of the heat loss can be eliminated or reduced, in theory, by adding a solenoid valve to stop the refrigerant migration during the heat pump off cycle. 


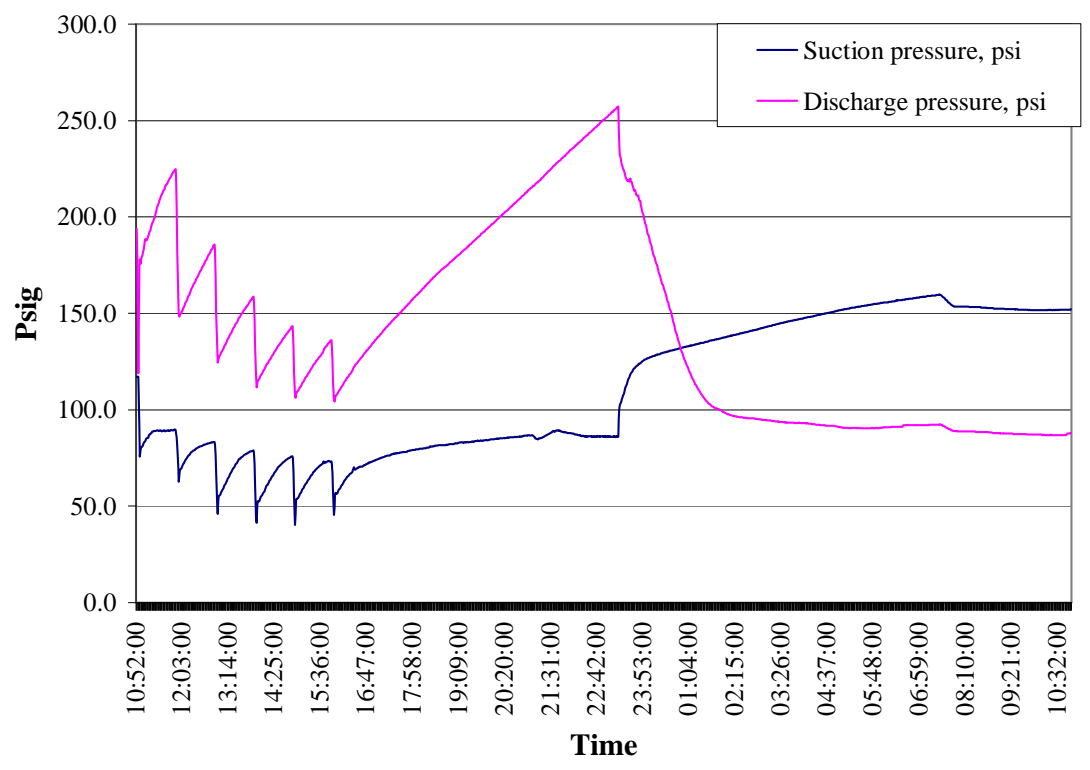

Fig. 7. Compressure discharge and suction pressure

In this test, the total energy drawn from the HPWH was 41,647 Btu. Total power input was 18,882 Btu. The EF achieved was 2.206. However, during the 10 hours when the compressor was off, the chamber room temperature drifted away from the set point, varying from 70 to $83^{\circ} \mathrm{F}$, which reduced the tank heat loss. The tank water temperature heat loss was recalculated by calculating the UA factor, which turned out to be a function of the tank water and room temperature differential. The final tank water temperature was adjusted from $134.7^{\circ} \mathrm{F}$ to $131.1^{\circ} \mathrm{F}$. The initial average tank water temperature before the test was $139.4^{\circ} \mathrm{F}$, so the power consumption required to heat the water from 131.1 to $139.4^{\circ} \mathrm{F}$ was calculated for the heat pump with a COP of 2.40 (calculated from test data with heat loss to the ambient discounted). Heat pump COP is always higher than EF because tank heat losses are a greater consideration due to the duration of the EF test). With these corrections, the revised EF becomes 2.02, which is more than twice as efficient as conventional electric water heaters.

Figure 8 shows the tank water temperature distribution. The tank was 60 in. tall, and 6 temperature sensors were evenly spaced inside the tank. The figure indicates that after the tank was fully charged, the temperature in the bottom sixth of the water was lower than that of the rest of the water by about $7^{\circ} \mathrm{F}$. It should be noted from the figure that the water temperature was stratified after the sixth draw. This indicates that the linear condenser does not generate undue temperature stratification inside the tank. The tested HPWH design was intended to heat water from the top first, because hot water would be drawn from the top of the tank first. If the design were modified by using the inner tube as the 
vapor line (in the current design it was used as the liquid return line), the tank would be heating from the bottom first.

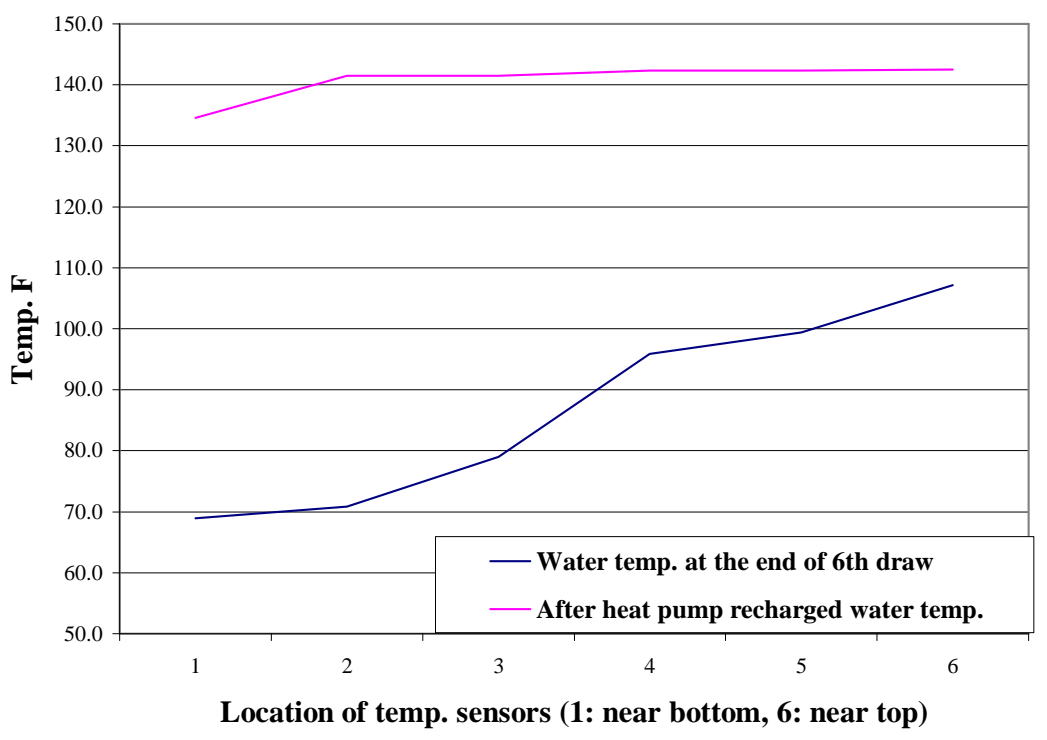

Fig. 8. Tank water temp. distribution

The tank heat loss to the ambient appeared to be substantial, even though it had a 3-in. layer of Styrofoam insulation. Figure 9 shows the calculated and curve-fitted UA values for the tank from the laboratory test data. For example, when the average tank temperature is at $126.3^{\circ} \mathrm{F}$ and the ambient is at $70^{\circ} \mathrm{F}$, the heat loss will be $230 \mathrm{Btu} / \mathrm{h}$ at a $\mathrm{UA}$ value of $4.08 \mathrm{Btu} / \mathrm{h} / \mathrm{F}$. This is because the two iron pipes on top of the tank, for hot water outlet and cold water inlet, act as two fins to transfer heat from the tank to the ambient. If we can insulate the pipes, along with the compressor discharge line, the heat pump performance will be improved. However, in real residential installation, the pipes will probably not be insulated. Other factors that support tank losses when the compressor is off may include thermosyphoning of heat inside the tank to the evaporator via the refrigerant. More work needs to be done to identify the extent of this behavior. 


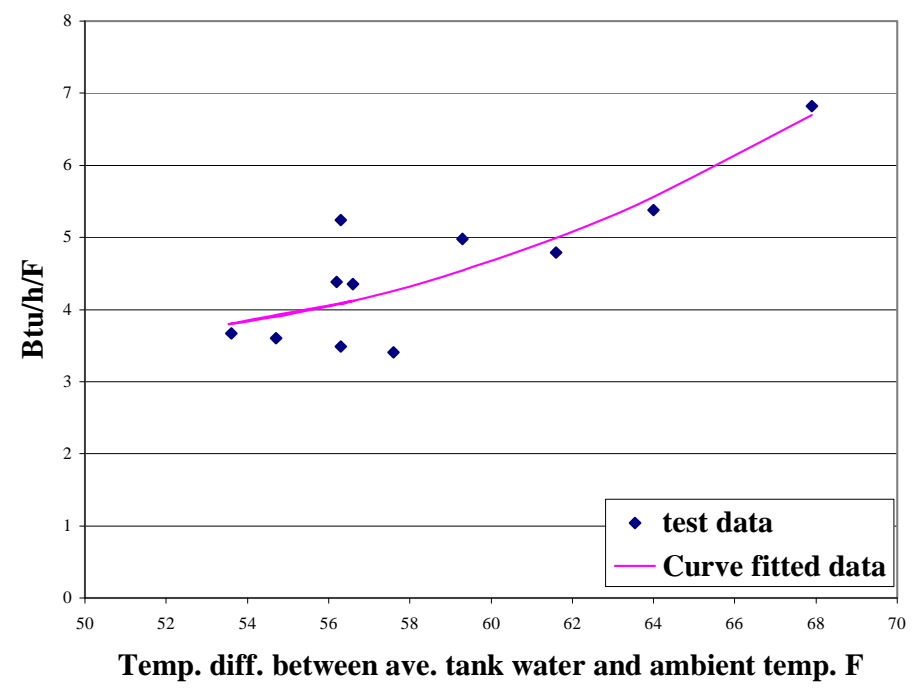

Fig. 9. Calculated and curve fitted UA values

\section{Conclusions}

A low-cost HPWH with a single-wall condenser coil inserted into the tank through two 7/8-in. holes on top of the tank was built and tested. The test conditions were based on the 1998 federal HPWH test standard. While two double-wall coils were formed, they were hardened after the inner coils went through expansion by pressure that was intended to form a better bond with the outer tubes. Inserting the double-wall coil into the tank could crack the coil. To be usable, the double-wall coil will have to be softened (by annealing); however, testing of a single-wall design was completed.

Two single-wall condenser coils were inserted into the tank from the two holes on top of the tank. Teflon tube of $1 / 4$-in. diameter was selected for its flexibility and its insulation value and used for the inner tube. We reached the following conclusions from the laboratory HPWH test.

1. The Teflon tube worked extremely well. Its workability was much better than that of the $1 / 4$-in. copper tubing. It reduced the heat exchange between vapor and liquid refrigerant, which improved the heat pump's performance.

2. A total of $70 \mathrm{ft}$ of 7/16-in. copper tubing was inserted into the tank. Because of sufficient heat transfer area, the compressor discharge pressure was never higher than 260 psig, which would be well within the normal compressor operating pressure range. The tank water temperature was easily heated to $140^{\circ} \mathrm{F}$.

3. There was no problem with inserting the 7/16-in. coil through the sleeve and into the tank. 
4. The revised EF calculated was 2.02, which is more than twice as efficient as standard electric water heaters.

5. The tank water temperature at the top was never below $107^{\circ} \mathrm{F}$ (which would be high enough for most applications) even after 6 hourly draws of a total of 64.5 gallons of water. No resistant heating was used throughout the test.

6. The tank has 3 in. of Styrofoam insulation around the tank, but heat loss to the ambient is still substantial because the iron pipes for hot water outlet and cold water inlet served as fins for heat transfer. If the two pipes are insulated, along with the compressor discharge lines, the performance of the system, or EF, can be further improved.

7. With this design, because the condenser coil reaches the bottom of the tank, the tank water temperature stratification was very minor, or was practically eliminated.

Based on the test data, an efficient and low-cost HPWH is feasible, and it can be built without any modification of the water tank design or water tank manufacturing processes. The results show that the design is efficient and the HPWH is simple to fabricate using a conventional, insulated hot water storage tank.

\section{E. References}

Mei, V. C., and C. Suhartoyo, 2004. "Development of an IDX Heat Pump Water Heater, A Final Progress Report to DOE and TVA,” Oak Ridge National Laboratory, Oak Ridge, TN. 37831

Mei, V. C., 2005. Personal communication on August 1, 2005, with Petur Thors of Wolverine on copper tube reheating to soften hardened tube. 